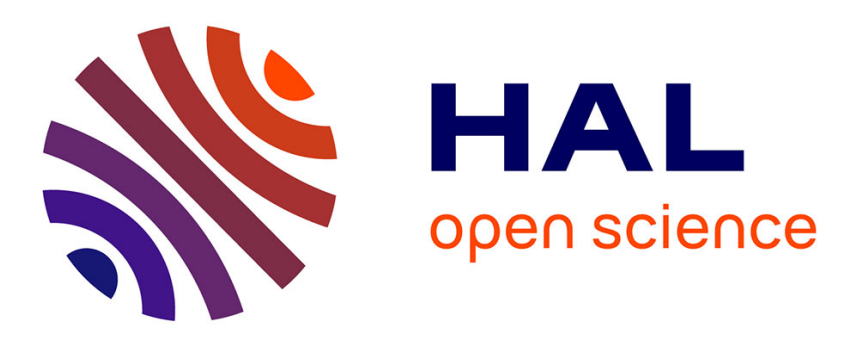

\title{
Identification of novel microsatellite loci in the sand martin, , and cross-amplification of loci from other bird species
}

\author{
Wouter F. D. Dongen, Gopi K. Munimanda, Jakob Augustin, Donald \\ Blomqvist, Tibor Szép, Richard H. Wagner
}

\section{To cite this version:}

Wouter F. D. Dongen, Gopi K. Munimanda, Jakob Augustin, Donald Blomqvist, Tibor Szép, et al.. Identification of novel microsatellite loci in the sand martin, , and cross-amplification of loci from other bird species. Journal für Ornithologie $=$ Journal of Ornithology, 2010, 151 (3), pp.761-764. 10.1007/s10336-010-0494-z . hal-00574009

\section{HAL Id: hal-00574009 \\ https://hal.science/hal-00574009}

Submitted on 7 Mar 2011

HAL is a multi-disciplinary open access archive for the deposit and dissemination of scientific research documents, whether they are published or not. The documents may come from teaching and research institutions in France or abroad, or from public or private research centers.
L'archive ouverte pluridisciplinaire HAL, est destinée au dépôt et à la diffusion de documents scientifiques de niveau recherche, publiés ou non, émanant des établissements d'enseignement et de recherche français ou étrangers, des laboratoires publics ou privés. 


\title{
Identification of novel microsatellite loci in the sand martin, Riparia riparia, and cross-amplification of loci from other bird species
}

\author{
Wouter F. D. van Dongen - Gopi K. Munimanda \\ Jakob Augustin • Donald Blomqvist · Tibor Szép • \\ Richard H. Wagner
}

Received: 17 August 2009/Revised: 7 November 2009/Accepted: 8 January 2010/Published online: 7 March 2010 (C) Dt. Ornithologen-Gesellschaft e.V. 2010

\begin{abstract}
We isolated and characterised six novel microsatellite loci for paternity analysis in the sand martin Riparia riparia, by screening an enriched genomic library. In addition, we tested 16 already published microsatellite markers, five of which were also polymorphic in the sand martin. Only one of these 11 loci exhibited evidence of null alleles, and all were polymorphic (mean $H_{\mathrm{o}}=0.68$, range of number of alleles per locus $=4-24$ ), making them suitable for individual heterozygosity quantification and paternity assessment in this species (exclusion probability of 11 unlinked loci $=0.999997$ ).
\end{abstract}

Keywords Sand Martin - Riparia riparia · Paternity . Microsatellite $\cdot$ Cross-amplification

Communicated by M. Wink.

W. F. D. van Dongen $(\varangle) \cdot$ G. K. Munimanda · R. H. Wagner Konrad Lorenz Institute for Ethology, Savoyenstrasse 1a, 1160 Vienna, Austria

e-mail: wouter.v.dongen@gmail.com

W. F. D. van Dongen

Departamento de Ciencias Ecológicas, Facultad de Ciencias, Universidad de Chile, Santiago, Chile

\section{J. Augustin · D. Blomqvist}

Department of Zoology, University of Gothenburg, Box 463, 40530 Gothenburg, Sweden

T. Szép

College of Nyíregyháza, Institute of Environmental Sciences, Nyíregyháza, Hungary

\section{Introduction}

The sand martin, Riparia riparia, is a small migratory passerine bird that breeds colonially in burrows dug into river banks in Eurasia and North America (where their common name is bank swallow). Genetic parentage analyses using multilocus DNA fingerprinting have revealed substantial frequencies of extra-pair paternity and intraspecific brood parasitism in this species (Alves and Bryant 1998; Augustin et al. 2007), while additional genetic analyses has revealed that telomere length, corrected for age, predicts longevity (Pauliny et al. 2006). Further, by being able to assign parentage of offspring within an isolated colony, we can test a prediction of the hidden lek hypothesis, namely that females acquire extra-pair fertilization from neighbouring males (Wagner 1993, 1998). We report here the development of novel microsatellite markers for the sand martin that will allow further investigation of these interesting patterns by (1) enabling the assignment of parentage to extra-pair and brood parasite offspring, thus allowing researchers to measure the fitness of alternative mating strategies in this system, and (2) allowing the calculation of heterozygosity to further examine fitness in tandem with telomere length and other variables. In addition, we describe several additional markers developed for other bird species that amplify sand martin microsatellite loci, thus augmenting the robustness of microsatellite analyses in this species.

\section{Methods}

Blood samples were taken from sand martins captured at colonies near the village of Gávavencsellő on the Tisza River, Hungary $\left(48^{\circ} 11^{\prime} \mathrm{N} 21^{\circ} 35^{\prime} \mathrm{E}\right)$ in 2004 and stored in 
Queen's lysis buffer. DNA was then extracted with phenol-chloroform-isoamyl alcohol. To isolate and identify microsatellite loci, we followed the method described by Farias et al. (2003). Briefly, mixed genomic DNA from four sand martins (two male and two female) was digested with MboI restriction enzyme and enriched for CT and CA microsatellite-containing fragments in polymerase chain reactions (PCRs). Fragments were then ligated into a PCR 2.1 TOPO vector. Clones that produced a clean, single, product after PCR were sequenced. We sequenced 26 clones that potentially contained CA repeats and 66 clones that potential contained CT repeats, using a Beckman Coulter CEQ 8000 automated sequencer. In total, six CA microsatellite loci and 12 CT loci were identified.
However, due to a problem with some microsatellite-containing fragments inserting into the vector with little or no flanking region, we could only design primers for two CA loci and seven CT loci. Primers were designed using Primer3 (Rozen and Skaletsky 2000).

Primer pairs that gave consistent, specific, products were tested for polymorphism. One primer in each pair was labelled with a fluorescent dye (D2-PA, D3-PA or D4-PA). The primer sequences and optimum annealing temperatures are listed in Table 1. We assessed polymorphism by typing at least 20 putatively unrelated individuals at each microsatellite locus. PCR was performed in $12.5 \mu \mathrm{l}$ reaction volumes containing a forward primer (labelled with a Beckman Coulter dye: D2, D3 or D4) and reverse primer

Table 1 Characterisation of novel microsatellite loci isolated in the sand martin Riparia riparia and cross-amplification of loci from other bird species

\begin{tabular}{|c|c|c|c|c|c|c|c|c|c|c|c|}
\hline Locus & Repeat motif in clone & Primer sequence $\left(5^{\prime}-3^{\prime}\right)$ & $N$ & $T_{\mathrm{a}}$ & {$\left[\mathrm{MgCl}_{2}\right]$} & $N_{\mathrm{a}}$ & bp & $H_{\mathrm{o}}$ & $H_{\mathrm{e}}$ & Ex & Reference \\
\hline Rri2 & $(\mathrm{CA})_{7} \mathrm{GGTA}(\mathrm{CA})_{4}$ & $\begin{array}{l}\text { F: CTAGGGTGAGTTTCACTTAAGC } \\
\text { R: CCGGTGAGTTTTGGAAAAGG }\end{array}$ & 21 & 50 & 3 & 6 & $343-365$ & 0.67 & 0.68 & 0.40 & This study \\
\hline Rri3 & $(\mathrm{CA})_{10}$ & $\begin{array}{l}\text { F: CCTTTAAACTGCTCCTGTACC } \\
\text { R: CAGAAAGTGTAGCGAAAAGG }\end{array}$ & 20 & 50 & 3 & 4 & 198-202 & 0.40 & 0.48 & 0.25 & This study \\
\hline Rri4 & $(\mathrm{CT})_{8}$ & $\begin{array}{l}\text { F: TTTACTCCCTGTCTCAGTCC } \\
\text { R: GGCTGAAAAGAGCATTCC }\end{array}$ & 21 & 60 & 3 & 5 & $154-162$ & 0.38 & 0.38 & 0.21 & This study \\
\hline Rri5 & $(\mathrm{CA})_{23}$ & $\begin{array}{l}\text { F: AACAGCACTGGAATTACTGG } \\
\text { R: GAGGAATCTGTGAACACACC }\end{array}$ & 20 & 60 & 4 & 24 & $231-559$ & 0.50 & 0.97 & 0.89 & This study \\
\hline Rri8 & $(\mathrm{CT})_{15}$ & $\begin{array}{l}\text { F: CAGAGTTCATGGAGCTTGTC } \\
\text { R: GATGAAACTTGGGATTGAGATG }\end{array}$ & 21 & 55 & 3 & 13 & $236-260$ & 0.81 & 0.92 & 0.79 & This study \\
\hline Rri9 & $(\mathrm{CT})_{15}$ & $\begin{array}{l}\text { F: CCAATGTGTTTCCACAGG } \\
\text { R: AGCTAAGAGCCAAGAAAACC }\end{array}$ & 23 & 55 & 3 & 12 & $324-346$ & 0.83 & 0.91 & 0.78 & This study \\
\hline Hru6 & $\begin{array}{l}(\mathrm{AAAG})_{17} \\
(\mathrm{AG})_{2}(\mathrm{AAAG})_{2}\end{array}$ & R: ACAGGGCAGTGITACTCTGC & 20 & 60 & 3 & 18 & $151-331$ & 0.90 & 0.95 & 0.85 & $\begin{array}{c}\text { Primmer } \\
\text { et al. } \\
\text { (1995) }\end{array}$ \\
\hline Hru7 & $\begin{array}{r}(\mathrm{AAACC})_{2} \\
(\mathrm{AAAC})_{3}\end{array}$ & R: GATCACTATGAGTCCCGAA & 20 & 60 & 3 & 5 & $132-144$ & 0.50 & 0.60 & 0.36 & $\begin{array}{c}\text { Primmer } \\
\text { et al. } \\
\text { (1995) }\end{array}$ \\
\hline $\operatorname{Esc} \mu 6$ & $\begin{array}{l}(\mathrm{CA})_{15} \mathrm{CG}(\mathrm{CA})_{10} \\
\mathrm{GATA}(\mathrm{CA})_{3}\end{array}$ & R: CCAAGTGCTCCTTAA & 20 & 60 & 3 & 21 & $129-205$ & 0.95 & 0.96 & 0.87 & $\begin{array}{l}\text { Hanotte } \\
\text { et al. } \\
\text { (1994) }\end{array}$ \\
\hline $\operatorname{Pdo} \mu 5$ & $(\mathrm{CA})_{3} \mathrm{G}(\mathrm{CA})_{21}$ & R: GCTGTGTTAATGCTATGAGG & 22 & 55 & 3 & 13 & $222-276$ & 0.82 & 0.80 & 0.62 & $\begin{array}{l}\text { Griffith } \\
\text { et al. } \\
\text { (1999) }\end{array}$ \\
\hline Aar4 & $(\mathrm{CA})_{13}$ & R: GTTTGTGCATCAATTAGTCATG & 22 & 60 & 3 & 8 & $109-129$ & 0.73 & 0.81 & 0.60 & $\begin{array}{c}\text { Hansson } \\
\text { et al. } \\
(2000)\end{array}$ \\
\hline
\end{tabular}

The number of individuals tested $(N)$, primer annealing temperature in ${ }^{\circ} \mathrm{C}\left(T_{\mathrm{a}}\right)$, the $\mathrm{MgCl}_{2}$ concentration in $\mathrm{mM}\left(\left[\mathrm{MgCl}_{2}\right]\right)$, number of alleles $\left(N_{\mathrm{a}}\right)$, allele size range in base pairs $(b p)$, observed $\left(H_{\mathrm{o}}\right)$ and expected $\left(H_{\mathrm{e}}\right)$ heterozygosity, and the probability of excluding a father $(\mathrm{Ex})$ are listed for each locus. Cloned Rri sequences have been deposited with GenBank under Accession numbers GQ372862-GQ372867 
(0.4 mM each), 0.625 units of FIREPol DNA polymerase, $1 \times$ reaction buffer, the optimal concentration of magnesium chloride $\left(\mathrm{MgCl}_{2}\right)$ (see Table 1$), 0.1 \mathrm{mM}$ deoxyribonucleotide triphosphates (dNTPs) and $25 \mathrm{ng}$ of genomic DNA. PCRs were run on a Biometra T1 thermocycler. An initial denaturation step $\left(94^{\circ} \mathrm{C}, 5 \mathrm{~min}\right)$ was followed by 30 cycles of $30 \mathrm{~s}$ at $94^{\circ} \mathrm{C}, 30 \mathrm{~s}$ at the locus-specific annealing temperature (Table 1), $60 \mathrm{~s}$ at $72^{\circ} \mathrm{C}$, and a final extension step for $10 \mathrm{~min}$ at $72^{\circ} \mathrm{C}$. The PCR products were subjected to electrophoresis on a Beckman Coulter CEQ 8000 automated sequencer, and fragment sizes were estimated with the Beckman Coulter CEQ 8000 fragment analysis software.

In addition to isolating novel microsatellite loci for the sand martin, we tested 16 existing microsatellite markers designed for other bird species for cross-amplification with sand martin DNA. Specifically, the primers tested were Hru1, 2, 3, 4, 5, 6, 7 and 8 (Primmer et al. 1995), Hru10 (Primmer et al. 1996), Pocc6 (Bensch et al. 1997), Esc $\mu 6$ (Hanotte et al. 1994), Мсу $\mu 6$ (Double et al. 1997), Ppi2 (Martinez et al. 1999), Ltr6 (McDonald and Potts 1994), Aar4 (Hansson et al. 2000) and Pdo $\mu 5$ (Griffith et al. 1999). We tested the polymorphism of six of these loci that consistently produced strong single PCR products.

\section{Results and discussion}

Of the nine novel loci isolated in the sand martin, one did not produce clean, scorable, alleles, and two were monomorphic. The remaining six were all polymorphic to a variable degree $\left(N_{\mathrm{a}}=4-24\right.$, mean $H_{\mathrm{o}}=0.60$; Table 1$)$. In addition, five published loci were polymorphic in this species $\left(N_{\mathrm{a}}=5-21\right.$, mean $H_{\mathrm{o}}=0.78$; Table 1$)$. Together, the novel and published loci exhibited a combined secondparent exclusion probability of 0.999997 (calculated using Cervus 3.0; Kalinowski et al. 2007). When additional tests implemented in Cervus 3.0 (Kalinowski et al. 2007) were used, only one locus (Rri5) was found to deviate significantly from Hardy-Weinberg equilibrium $(P<0.001)$. This locus showed evidence of heterozygote deficiency, possibly due to the presence of null alleles. However, the polymorphism of this locus (24 alleles from 20 typed individuals) and allele size range (231-559 bp) suggested that at least some of those individuals typed as homozygotes might, in fact, have had alleles larger than the maximum read range of the Beckman Coulter fragment analysis software $(600 \mathrm{bp})$. We were unfortunately unable to sequence the entire length of the Rri5 locus and so have little information on the exact characteristics of this locus. The omission of this locus from parentage analysis still resulted in a very high second-parent exclusion probability of 0.99997. Using GENEPOP (Raymond and Rousset
1995), we found no evidence of linkage disequilibrium between the loci (all $P>0.05$ ). This set of 11 markers will, therefore, be a valuable tool for documenting patterns of paternity and heterozygosity levels in the sand martin.

Acknowledgments We thank Yoshan Moodley, Anna Grasse and Tomas Hrbek for technical advice during loci isolation and characterisation and Zsolt Nagy for assisting with field work. This research was funded by the Austrian Academy of Sciences and by OTKA grants (T042879, K69068) awarded to T.S. Blood samples were collected under permits issued by the Hortobágy National Park (2266/2004)

\section{References}

Alves MAS, Bryant DM (1998) Brood parasitism in the sand martin, Riparia riparia: evidence for two parasitic strategies in a colonial passerine. Anim Behav 56:1323-1331

Augustin J, Blomqvist D, Szép T, Szabo ZD, Wagner RH (2007) No evidence of genetic benefits from extra-pair fertilizations in female sand martins (Riparia riparia). J Ornithol 148:189-198

Bensch S, Price T, Kohn J (1997) Isolation and characterization of microsatellite loci in a Phylloscopus warbler. Mol Ecol 6:91-92

Double MC, Dawson D, Burke T, Cockburn A (1997) Finding the fathers in the least faithful bird: a microsatellite-based genotyping system for the superb fairy-wren Malurus cyaneus. Mol Ecol 6:691-693

Farias IP, Hrbek T, Brinkmann H, Sampaio I, Meyer A (2003) Characterization and isolation of DNA microsatellite primers for Arapaima gigas, an economically important but severely overexploited fish species of the Amazon basin. Mol Ecol Notes 3:128-130

Griffith SC, Stewart IRK, Dawson DA, Owens IPF, Burke T (1999) Contrasting levels of extra-pair paternity in mainland and island populations of the house sparrow (Passer domesticus): is there an 'island effect'? Biol J Linn Soc 68:303-316

Hanotte O, Zanon C, Pugh A, Greig C, Dixon A, Burke T (1994) Isolation and characterization of microsatellite loci in a passerine bird: the reed bunting Emberiza schoeniclus. Mol Ecol 3:529530

Hansson B, Bensch S, Hasselquist D, Lillandt B, Wennerberg L, von Schantz T (2000) Increase of genetic variation over time in a recently founded population of great reed warblers (Acrocephalus arundinaceus) revealed by microsatellites and DNA fingerprinting. Mol Ecol 9:1529-1538

Kalinowski S, Taper M, Marshall T (2007) Revising how the computer program CERVUS accommodates genotyping error increases success in paternity assignment. Mol Ecol 16:10991106

Martinez JG, Soler JJ, Soler M, Møller AP, Burke T (1999) Comparative population structure and gene flow of a brood parasite, the great spotted cuckoo (Clamator glandarius), and its primary host, the magpie (Pica pica). Evolution 53:269-278

McDonald DB, Potts WK (1994) Cooperative display and relatedness among males in a lek-mating bird. Science 266:1030-1032

Pauliny A, Wagner RH, Augustin J, Szép T, Blomqvist D (2006) Ageindependent telomere length predicts fitness in two bird species. Mol Ecol 15:1681-1687

Primmer CR, Møller AP, Ellegren H (1995) Resolving genetic relationships with microsatellite markers: a parentage testing system for the swallow Hirundo rustica. Mol Ecol 4:493-498 
Primmer C, Møller AP, Ellegren H (1996) New microsatellites from the pied flycatcher Ficedula hypoleuca and the swallow Hirundo rustica genomes. Hereditas 124:281-283

Raymond M, Rousset F (1995) GENEPOP (version 1.2): population genetics software for exact tests and ecumenicism. J Hered $86: 248-249$

Rozen S, Skaletsky H (2000) Primer3 on the WWW for general users and for biologist programmers. In: Krawetz S, Misener S (eds) Bioinformatics methods and protocols: methods in molecular biology. Humana Press, Totowa, pp 365-386
Wagner RH (1993) The pursuit of extra-pair copulations by female birds: a new hypothesis of colony formation. J Theor Biol 163:333-346

Wagner RH (1998) Hidden leks: sexual selection and the clustering of avian territories. In: Parker PG, Burley N (eds) Avian reproductive tactics: female and male perspectives. Ornithological Monograph, vol 49. American Ornithologists' Union, Washington, DC, pp 123-145 